\title{
Ortaokul ve Lise Öğrencilerinin Kamu Harcaması Bilinçlerinin Tespitine ve Geliştirilmesine Yönelik Bir Deney
}

\begin{abstract}
Ortaokul ve Lise Öğrencilerinin Kamu Harcaması Bilinçlerinin Tespitine ve Geliştirilmesine Yönelik Bir Deney

Öz

Yetişkin mükelleflerin vergi ile ilgili alışkanlıklarını değiştirmek güçtür. Bu yüzden bugünün olabileceği gibi geleceğin de mükellefleri olabilecek öğrenciler için çalışmalar yapılması önem arz etmektedir. Öğrencilerin mali bilinçlerinin geliştirilmesi için kamu harcaması bilinçlerinin de geliştirilmesi gerekmektedir. Buna göre bu çalışmanın amacı öğrencilerin kamu harcaması bilinçlerinin tespit edilmesi ve geliştirilmesidir. Bu bağlamda öğrencilere açık uçlu soru yöneltilmiştir. Daha sonra öğrencilerin kamu harcaması bilinçlerini geliştiren bir deney yapılmıştır. Deney sonrasında öğrencilere açık uçlu soru tekrar yöneltilmiş ve kamu harcaması bilinçleri tespit edilmiştir. Deney öncesinde öğrencilerin kamu harcaması bilinçlerinin çok düşük olduğu, sonrasında öğrencilerin kamu harcaması bilinçlerinin yüksek olduğu ve böylelikle geliştirilebildiği tespit edilmiştir. Bu çalışmada elde edilen bulgularla gelecek çalışmalarda kullanılmak üzere öğrencilerin kamu harcaması bilinçlerini tespit eden Likert ölçekli bir soru geliştirilmiştir.
\end{abstract}

Anahtar Kelimeler: Vergi Kültürü, Mali Bilinç, Kamu Harcaması Bilinci, Vergi Uyumu, Öğrenci
An Experiment for Determining and Developing Public Expenditure Awareness of Secondary and High School Students

Abstract

It is difficult to change their tax-related habits of adult taxpayers. Therefore, it is important to carry out studies for students who maybe taxpayers of the today or future. In order to improve students' financial awareness, public expenditure awareness should be improved.Accordingly, the purpose of this study is to determine and improve students' public expenditure awareness. In this context, open-ended questions were asked to the students. Then, an experiment was developed to improve students' public expenditure awareness. After the experiment, the open-ended question was directed to the students again and their public expenditure awareness was determined. It was determined that students 'public expenditure awareness was very low before the experiment and students'public expenditure awareness was high and thus they could be improved after the experiment. With the findings obtained in the study, a Likert scale question has been developed that determines the students'public expenditure awareness to be used in future studies.

Keywords: Tax Culture, Fiscal Awareness, Public Expenditure Awareness, Tax Compliance, Student

\section{Giriş}

Bir ülkedeki vergi kültürünün yerleşmiş olmasının gönüllü vergi uyumuna pozitif etki yaptığı bilinmektedir. Gönüllü vergi uyumunun sağlanmasında vergi kültürünün yerleşmesinin öneminin anlaşılmasını takiben vergi kültürünün yerleşmesi için mükellefler ve gelecekteki mükellefler için çalışmalar yapılmaktadır.

Türkiye'de gelecekteki vergi mükelleflerinin gönüllü vergi uyumunu artırmak için T.C. Milli Eğitim Bakanlığı ve T.C. Maliye ve Hazine Bakanlığı arasında 13.06.2007 tarihinde "verGiBilir Protokolü" imzalanmıştır. Protokol, öğrencilerin vergi ile ilgili oluşmuş ve oluşacak olan algılarını pozitif yönlendirecek içerikler ile uzun vadede vergi kültürlerini ve bu bağlamda gönüllü vergi uyumlarını artırmayı amaçlamaktadır.

Devlet eliyle sunulan kamu harcamalarının finansmanı için vergilere ihtiyaç duyulmaktadır ve bu ihtiyacın karşılanmasına katkı sağlayan unsurlardan biri mükelleflerin mali bağlantı ilişkisini kurabilmesi ile ilgilidir. Mali bağlantı, toplum için yapılan harcamalar ile bu harcamaların finansmanı olan vergiler arasındaki ilişkinin kurulması halinde sağlanabilmektedir (Demir,

\footnotetext{
${ }^{1}$ Dr., yaseminariman@hotmail.com, Yazar ORCID bilgisi: https://orcid.org/0000-0002-4325-7768
} 
2009). Buna göre mali bağlantının kurulabilmesi için mükelleflerin mali bilincinin, bir başka ifade ile vergi ve kamu harcamaları bilincinin, belli bir seviyenin üzerinde olmasının gerektiği söylenebilir.

Mükelleflerin kamu harcamalarının hangi harcamalar olduğu ve toplumsal yaşam için ne denli önemli olduğu bilgisine sahip olmayışları, kamu harcamalarını gereksiz bulmalarına, mantıksız ve etkinsiz yapıldıklarını düşünmelerine neden olabilir. Böylesi bir durumda mükelleflerin vergiye gönüllü uyumlarının azalacağı söylenebilir. Bu bağlamda mükelleflere ve geleceğin mükelleflerine, devlet eliyle sunulan tüm kamusal mal ve hizmetler hakkında bilgi verilmeli, ne denli önemli oldukları bildirilmeli ve bu hizmetlerin sunulamamaları halinde hem toplum olarak hem de bireysel olarak ne ile karşılaşabilecekleri bilgisi paylaşılmalıdır. Böylelikle mükelleflerin ve geleceğin mükelleflerinin sunulan kamusal mal ve hizmetlerin ne denli önemli olduğu ve nedenli gerekli olduğu bilgisine sahip olmaları ile vergiye gönüllü uyum göstermeleri sağlanmış olacaktır.

Öğrencilere vergiler, kamu harcamaları, mükelleflerin vergilerini nasıl ödeyecekleri, gelir idareleri ve mükellef haklarına yönelik bilgileri kapsayan eğitimlerin verildiği bilinmektedir (OECD, 2015: 91). Türkiye'de öğrencilerin vergi bilincini tespit eden ve geliştiren çalışmalar yapılmıştır (Sağbaş ve Başoğlu, 2005; Karaot, 2010; Taytak, 2010; Zorlu, 2012; Çelik ve Eroğlu, 2014; Karaca, 2015; Demir ve Ciğerci, 2016; ). Vergi bilincinin mali bilincin bir parçası olmakla birlikte gönüllü vergi uyumunu artırmak için tek başına yeterli olamayacağı söylenebilir. Bu bağlamda kamu harcaması bilinci tespitinin ve geliştirilmesinin gönüllü vergi uyumunu artırmak için gerekli olduğu söylenebilir. Böylelikle mali bağlantı kurulmasının kolaylaştırılması ve dolayısıyla mali bilincin artırılması için kamu harcaması bilincinin tespitine ve geliştirilmesine yönelik yapılacak çalışmalar önem arz etmektedir.

Bu çalışmanın amacı ortaokul ve lise öğrencilerinin kamu harcaması bilinçlerini tespit etmek ve sonrasında geliştirilebilmesi için önerilerde bulunmaktır. Çalışma Trabzon ilindeki ortaokul ve lise öğrencilerini kapsamaktadır. Bu bağlamda öncelikle çalışma konusu ile ilgili literatür taraması yapılmıştır. Daha sonra öğrencilerin kamu harcaması bilincini geliştirmek amacıyla bir deney tasarlanmıştır. Söz konusu deney Trabzon Faruk Başaran Bilim ve Sanat Merkezinde yapılmıştır. Öğrencilerin kamu harcaması bilinçlerini tespit etmek için vergi bilincini ölçen Vergi Nedir? sorusundan esinlenilerek Sizce Kamu Harcaması Nedir? sorusu hazırlanmış ve açık uçlu bir soru olarak deney öncesinde ve sonrasında öğrencilere yöneltilmiştir. Öğrencilere yöneltilen bu açık uçlu soruya verilen cevaplar doğrultusunda gelecek çalışmalarda kullanılmak üzere kamu harcaması bilinci tespiti için 5'li Likert ölçeğinin kullanıldığı soru geliştirilmiştir.

Çalışmada ilk olarak teorik ve kavramsal çerçeveye; mali sosyoloji, mali bağlantı, mali bilinç ve kamu harcaması bilincine ve önemine yer verilmekte, takiben ilgili literatür taramasına yer verilmektedir. İkinci olarak çalışmanın yöntemine, bulgularına ve çalışma ile elde edilenlere yer verilerek önerilerde bulunulmaktadır.

\section{Teori ve Kavramsal Çerçeve}

Bu başlık altında çalışmanın teorik ve kavramsal çerçevesine yer verilmektedir. Buna göre mali sosyoloji, mali bağlantı, mali bilinç, kamu harcaması kavramlarına yer verilmektedir. Daha sonra kamu harcaması bilincine ve bu bilincin gönüllü vergi uyumu için neden önemli olduğuna yer verilmektedir. 


\subsection{Mali Sosyoloji, Mali Bağlantı ve Mali Bilinç}

Toplumun mali konular hakkında oluşum-işleyiş ve gelişim yasalarını inceleyen, bu toplumla ilgili mali olayları bu yasalar doğrultusunda ele alan (Goldscheid, 1958: 202) ve sosyoloji disiplininin bir alt dalı olan mali sosyoloji; tüm toplumlar ve bireyler için aynı olması beklenen mali olayların sonuçlarının farklılık nedenlerini açıklamaktadır. Maliye tarihi süresince ekonomik yaklaşımların mali olayları açıklamada yetersiz oluşu, mali olayların ekonomik boyutuyla birlikte sosyoloji ve psikoloji boyutuyla da değerlendirilmesini gerekli kılmıştır (Goldscheid, 1958; Schmölders, 1976). Mali olaylar psikolojik boyutlarıyla değerlendirildiğinde; mali bağlantının, uygulanan mali politikalar ve özellikle vergi uyumu politikaları için ne derece önem arz ettiğini göstermektedir.

Mali bağlantı, toplum için yapılan harcamalar ile bu harcamaların finansmanı olan vergiler arasındaki ilişkinin kurulmasıdır. Mali bağlantının kurulabilmesi için mali bilincin bir başka ifade ile vergi ve kamu harcamaları bilincinin belli bir seviyenin üzerinde olması gerekmektedir. Vergi bilinci, mükelleflerin vergi ile ilgili konularda bilgi sahibi olması ve aynı zamanda vergilerin kamu hizmetleri için ödendiği bilgisine sahip olması olarak tanımlanabilir (Taytak, 2010: 498).

\subsection{Kamu Harcaması Bilinci ve Önemi}

Kamu harcaması toplumun ortak ihtiyaçlarının karşılanması için devlet eliyle yapılan ve finansmanı kamu gelirleri ile karşılanan harcamalardır. Toplumdaki her birey için hayati derecede önemli olan bu harcamalar, fonksiyonel sınıflandırmaya göre; genel kamu, savunma, kamu düzeni ve güvenlik, ekonomik işler, çevre koruma, iskân ve toplum refahı, sağlık, dinlenme, kültür ve din, eğitim, sosyal güvenlik ve sosyal yardım ihtiyaçları için yapılan harcamalardır. Söz konusu bu ihtiyaçlar aynı zamanda fonksiyonel sınıflandırmaya göre I. Düzeyde kamu harcama kalemlerinin isimleridir (Analitik Bütçe Sınıflandırmasına İlişsin Rehber). Fonksiyonel sınıflandırmaya göre kamu harcamaları II. Düzey içeriklerine Tablo 1'de yer verilmektedir.

Tablo 1: Fonksiyonel Sınıflandırmaya Göre Kamu Harcamaları

\begin{tabular}{|c|c|}
\hline $\begin{array}{l}\text { Fonksiyonel } \\
\text { Sınıflandırma } \\
\text { II. Düzey }\end{array}$ & İçerik \\
\hline Genel Kamu Hizmetleri & $\begin{array}{l}\text { Yasama ve yürütme organları, finansal ve mali işler, dışişleri, dış ekonomik } \\
\text { yardım, genel, temel araştırma, borç yönetimi, genel nitelikli transferlere } \\
\text { ilişkin, genel kamu hizmetlerine ilişkin araştırma ve geliştirme ve } \\
\text { sınıflandırmaya girmeyen genel kamu hizmetleri }\end{array}$ \\
\hline Savunma Hizmetleri & $\begin{array}{l}\text { Askeri ve sivil savunma, dış askeri yardım, savunmaya ilişkin AR-GE ve } \\
\text { sınıflandırmaya girmeyen savunma hizmetleri }\end{array}$ \\
\hline Kamu Düzeni ve & Güvenlik, yangından korunma, mahkeme, cezaevi idaresi, kamu düzeni ve \\
\hline Güvenlik Hizmetleri & $\begin{array}{l}\text { güvenliğe iliş̧kin AR-GE, sınıflandırmaya girmeyen kamu düzeni ve güvenlik } \\
\text { hizmetleri }\end{array}$ \\
\hline $\begin{array}{l}\text { Ekonomik İşler ve } \\
\text { Hizmetler }\end{array}$ & $\begin{array}{l}\text { Genel ekonomik işler ve hizmetler, tarım, ormancılık, balıkçılık ve avcılık, } \\
\text { yakıt ve enerji, madencilik, imalat ve inşaat, ulaştırma ve iletişim hizmetleri, } \\
\text { diğer endüstriler, ekonomik faaliyetlere ilişkin AR-GE, sınıflandırmaya } \\
\text { girmeyen ekonomik işler ve hizmetleri }\end{array}$ \\
\hline Çevre Koruma Hizmetleri & $\begin{array}{l}\text { Atık yönetimi, atık su yönetimi ve kirliliğin azaltılması hizmetleri, doğal } \\
\text { ortamın ve bio çeşitliliğin korunması, çevre korumaya ilişkin AR-GE ve } \\
\text { sınıflandırmaya girmeyen çevre koruma hizmetleri }\end{array}$ \\
\hline $\begin{array}{l}\text { İskân ve Toplum Refahı } \\
\text { Hizmetleri }\end{array}$ & $\begin{array}{l}\text { İskân işleri, toplum refahı, su temini işleri, sokak ve caddelerin aydınlatılması, } \\
\text { iskân ve toplum refahına ilişkin AR-GE ve sınıflandırmaya girmeyen iskân ve } \\
\text { toplum refahı hizmetleri }\end{array}$ \\
\hline Sağlık Hizmetleri & $\begin{array}{l}\text { Tıbbi ürünler, cihaz ve ekipmanlara ilişkin işler ve hizmetler, ayakta yürütülen } \\
\text { tedavi, hastane işleri ve hizmetleri, halk sağlığı, sağlık hizmetlerine ilişkin }\end{array}$ \\
\hline
\end{tabular}




\begin{tabular}{|c|c|}
\hline & AR-GE ve sınıflandırmaya girmeyen sağıık hizmetleri \\
\hline Dinlenme, Kültür ve & Dinlenme ve spor, kültür, yayın ve yayım, din, dinlenme, kültür ve din \\
\hline Din Hizmetleri & $\begin{array}{l}\text { hizmetlerine ilişkin AR-GE ve sınıflandırmaya girmeyen dinlenme, kültür ve } \\
\text { din hizmetleri }\end{array}$ \\
\hline Eğitim Hizmetleri & $\begin{array}{l}\text { Okul öncesi ve ilköğretim, ortaöğretim, ortaöğretim sonrası mesleki eğitim, } \\
\text { yükseköğretim, seviyeye göre sınıflandırılamayan eğitim, eğitime yardımcı, } \\
\text { eğitime ilişkin AR-GE ve sınıflandırmaya girmeyen eğitim hizmetleri }\end{array}$ \\
\hline $\begin{array}{l}\text { Sosyal Güvenlik ve } \\
\text { Sosyal Yardım Hizmetleri }\end{array}$ & $\begin{array}{l}\text { Hastalık ve malullük yardım, yaşlılık, dul ve yetim aylığı, aile ve çocuk yardımı, } \\
\text { işsizlik yardımı, iskân yardımı, sosyal güvenliği bulunmayanlara sağlanan, } \\
\text { Sosyal güvenlik ve sosyal yardımlara ilişkin AR-GE ve sınıflandırmaya } \\
\text { girmeyen sosyal güvenlik ve sosyal yardım hizmetleri }\end{array}$ \\
\hline
\end{tabular}

Kamu harcamaları sınıflandırmalarından biri olan ekonomik sınıflandırmaya göre harcamaları; personel, sosyal güvenlik kurumlarına devlet primi, mal ve hizmet alım ve faiz giderleri, cari transferler, sermaye giderleri, sermaye transferleri, borç verme ve yedek ödeneklerden oluşmaktadır. Aynı zamanda bu harcamalar ekonomik sınıflandırma I. Düzeyde kamu harcama kalemlerinin isimleridir.

Kamu harcaması bilinci, yukarıda yer verilen vergi bilinci tanımından hareketle, mükelleflerin kamu harcamaları hakkında bilgi sahibi olması ve aynı zamanda bu harcamaların toplumun ihtiyaçları doğrultusunda yapılan harcamalar olduğu bilgisine sahip olması olarak tanımlanabilir. Buna göre mükellefler fonksiyonel sınıflandırmaya ya da ekonomik sınıflandırmaya göre kamu harcamalarının içeriği hakkında bilgi sahibi olmalıdır. Bu bağlamda kamu harcamalarının fonksiyonel sınıflandırmasının, mükelleflerin harcamaları kavramasını kolaylaştıracağı ve kamu harcama bilincini artırmaya ekonomik sınıflandırmaya göre daha fazla katkı sağlayacağı söylenebilir. Aynı zamanda kamu harcamalarının fonksiyonel sınıflandırması uluslararası karşılaştırmalara imkân sağlayan bir sınıflandırma türüdür (Pehlivan, 2015: 150). Bu nedenle bu çalışmada fonksiyonel sınıflandırmaya göre kamu harcaması sınıflandırması kullanılmaktadır.

Bilindiği üzere toplumsal mal ve hizmetler devlet eliyle kamu harcamaları yapılmak suretiyle sağlanmaktadır. Mükelleflerin, bu harcamalar hakkındaki bilgilerden yoksun olmalarının, kamusal mal ve hizmetlerin finansmanına katılma isteklerini azalttığı ya da azaltacağı söylenebilir. Mükelleflerin söz konusu bu bilgilerden yoksun olmalarının mali bağlantı kurma yeteneklerini negatif etkilediği de söylenebilir. Buna göre mükelleflerin mali bağlantıyı yeterince kuramıyor olmalarının vergiye uyumsuzluk göstermelerine neden olduğu söylenebilir. Dolayısıyla toplumun ihtiyaçlarının karşılanması ve mükelleflerin vergiye uyum göstermelerinin tam olabilmesi, diğer bir ifadeyle mükelleflerin vergi ile ilgili işlemlerini tam ve zamanında yerine getirebilmesi için kamu harcaması bilinçlerinin olmasına ve geliştirilmesine ihtiyaç olduğu söylenebilir.

Bireylerin davranışları, algı-tutum-davranış hiyerarşisinde meydana gelmektedir. Bu bağlamda mükelleflerin kamu harcaması bilincinin oluşması kamu harcaması algısı ile başlayacaktır. Bireylerin algısını belirleyen yirmi faktör olduğu ileri sürülmektedir. Buna göre bu faktörler; dikkat, yoğunluk, büyüklük, yer, renk, şekil, hareketlilik, yenilik, tecrübeler ve öğrenilenlerin etkisi, ilgi, ihtiyaç ve güdüler, kişisel özellikler ve ruhsal durum, sosyal etkenler, tekrar, basitlik, optik aldanma, abartma, genelleme, beklentiler, ortam ve şartlandırmadır (Göksu, 2007). Böylece mükelleflerin kamu harcaması algısının bu faktörlerden etkileneceği söylenebilir. 


\section{3. İlgili Literatür}

Bu başlık altında öğrencilerin kamu harcaması bilinçlerinin tespitine ve geliştirilmesine yönelik yapılmış çalışmalara yer verilmektedir. Bu çalışma Türkiye'de öğrencilerin kamu harcaması bilinçlerinin tespit edilmesi ve geliştirilmesine yönelik hazırlanmaktadır. Bu bağlamda çalışma ile ilgili literatür Türkiye'deki öğrenciler ile ilgili yapılan anket ve mülakat çalışmalarıyla sınırlandırılmıştır. İlgili literatür için elde edilen bulgulara Tablo 2 ve 3 ' te yer verilmektedir.

Tablo 2: Vergi Nedir?

\begin{tabular}{|c|c|c|c|}
\hline Vergi Nedir? & $\begin{array}{l}\text { Halka hizmet için } \\
\text { alınan ücret }\end{array}$ & $\begin{array}{l}\text { Devlet hizmet- } \\
\text { leri için verilen } \\
\text { para }\end{array}$ & $\begin{array}{l}\text { Devletin sun- } \\
\text { duğu mal ve } \\
\text { hiz-metlerin } \\
\text { karşılığı }\end{array}$ \\
\hline Demir ve Ciğerci, 2016: 134 & $\% 3$ & \%15,5 & $(-)$ \\
\hline Demir ve Ciğerci, 2016: 134/1 & $\% 8$ & $\% 52,5$ & $(-)$ \\
\hline Zorlu, 2012: 66 & $(-)$ & $(-)$ & $\% 53,1$ \\
\hline Sağbaş ve Başoğlu, 2005: 132 & $(-)$ & $(-)$ & $\% 9$ \\
\hline Karaot, 2010: 75 & $\% 32$ & $(-)$ & $(-)$ \\
\hline Taytak, 2010: 506 & $(-)$ & $(-)$ & $\% 44,3$ \\
\hline Karaca, 2015: 61 & $(-)$ & $(-)$ & $\% 47,6$ \\
\hline Çelik ve Eroğlu, 2014: 312 & $(-)$ & $(-)$ & $\% 40,5$ \\
\hline
\end{tabular}

Türkiye'de ortaokul ve lise öğrencilerinin vergi bilincinin tespitine yönelik yapılmış olan anket ve mülakat çalışmaları Tablo 2'de görülmektedir. Buna göre öğrencilerin bir kısmının, vergilerin kamusal mal ve hizmetlerin karşılığı olarak ödendiğini ifade ettiği görülmektedir (Sağbaş ve Başoğlu, 2005: 132 Demir ve Ciğerci, 2016: 134 Karaot, 2010: 75 Taytak, 2010: 506 Zorlu, 2012: 66 Çelik ve Eroğlu, 2014: 312 Karaca, 2015: 61). Bu bağlamda öğrencilerin bir kısmının kamusal mal ve hizmetler hakkında bilgi sahibi olduğu ve bu hizmetler karşılığında vergi ödendiği bilgisine sahip oldukları söylenebilir. Ortaokul 6. sınıf öğrencilerinin sosyal bilgiler ders kitabında "Türkiye Cumhuriyeti Vatandaşı Olarak Sorumluluklarımız" başlığı altında öğrencilere vergi verme sorumluluğu öğretilmektedir. Buna göre, öğrencilere bu bilgi ders kitapları aracıllğıyla 6. sınıfta sağlanmaktadır. Bunun yanı sıra öğrenciler bu bilgiyi ailelerinden ve sosyal çevrelerinden hatta kendi gözlemlerinden de elde etmiş olabilirler.

Tablo 3: Sizce vergisini ödemeyen insanlar neden vergilerini ödememektedir?

\begin{tabular}{|c|c|c|}
\hline $\begin{array}{c}\text { Sizce Vergisini Ödemeyen İn- } \\
\text { sanlar Neden Vergilerini Öde- } \\
\text { memektedir? }\end{array}$ & $\begin{array}{l}\text { Vergiler gereksiz yere } \\
\text { kullanıldıkları için }\end{array}$ & $\begin{array}{l}\text { Vergiler doğru yere harcan- } \\
\text { madığı için }\end{array}$ \\
\hline Zorlu, 2012: 70 & $\% 16,7$ & $(-)$ \\
\hline Sağbaş ve Başoğlu, 2005: 138 & $(-)$ & $\% 8,2$ \\
\hline Karaot, 2010: 90 & $\begin{array}{l}(-) \\
(-)\end{array}$ & $\% 31$ \\
\hline Çelik ve Eroğlu, 2014: 311 & $(-)$ & $\% 42,9$ \\
\hline
\end{tabular}

Toplanan vergi gelirlerinin nasıl, nerelere ve ne oranda harcandığı mükelleflerin vergi uyumlarını etkilediği söylenebilir. Bu bağlamda Tablo 3'ten öğrencilerin, "vergilerin doğru yerlere harcanmadı̆̆ı" düşüncesiyle mükelleflerin vergisel yükümlülüklerini yerine getirmediklerini ifade ettikleri görülmektedir (Sağbaş ve Başoğlu, 2005: 138 Karaot, 2010: 90 Çelik ve Eroğlu, 2014:311). Bu bağlamda yapılan çalışmalarda, anket ve mülakat çalışmasına katılan öğrencilerin 
bir kısmının mali bağlantı kurabildiği ancak bu bağlantının gönüllü vergi uyumunu artırmaya yönelik olmadığı, kamu harcamalarına yönelik negatif algılarının olduğu söylenebilir.

\section{Araştırma}

Bu başlık altında araştırmanın nerede, kimlerle yapıldığına ve nasıl yürütüldüğüne diğer bir ifadeyle yöntemine, deney öncesinde ve sonrasında elde edilen bulgularına ve sonuçlarına yer verilmektedir.

\subsection{Araştırmanın Yöntemi}

Bugün okul sıralarında oturan öğrencilerin gelecekte birer mükellef olacakları düşünülmektedir. Geleceğin mükelleflerinin toplum-devlet ve toplumsal hizmetler arasındaki ilişkiyi kavramalarının, gelecekte vergisel yükümlülüklerini tam ve zamanında yerine getirmelerine katkı sağlayacağı söylenebilir. Bu nedenle aile ve sosyal çevrelerinden mali bilinçlerinin doğru oluşmasını engelleyecek her türlü tehdide karşın daha okula başladıkları ilk yıllardan itibaren vergi ve kamu harcamaları ile ilgili eğitilmeleri-öğretilmeleri, gelecekte mali bağlantının kurulması ve dolayısıyla vergi uyumunun artırılması için önem arz etmektedir.

13 Haziran 2007'de T.C. Maliye ve Hazine Bakanlığı ve T.C. Milli Eğitim Bakanlığı arasında "verGiBilir Çalışma Protokolü" imzalanmıştır. "Bu protokolün temel amacı, çocukların vergi ile ilgili olumlu tutum oluşturmalarını ya da mevcut tutumlarını olumlu yönde değiştirmelerini sağlamaktır". Bu bağlamda bakanlık tarafından vergi kültürünü geliştirmek ve vergi bilinci yerleştirmek için çalışmalar yapıldığı ancak mali bağlantı kurulmasına ve vergi bilincinin artırılmasına yardımcı olacak kamu harcaması bilincinin artırılması için henüz bir çalışma yapılmadığı söylenebilir. Ayrıca söz konusu protokolde vergi bilinci için öngörülen eğitimlerin, eğitim süreçleri ilkokul-ortaokul ve lise öğrencilerini kapsamaktadır.

Ortaokul ve lise öğrencilerinin kamu harcaması bilinçlerini ölçmek ve geliştirmek amacıyla Trabzon ilinde Faruk Başaran Bilim ve Sanat Merkezinde bir laboratuvar deneyi yapılmıştır. Daha önce yapılmış olan çalışmalardan yararlanılarak, öncelikle ortaokul ve lise öğrencilerinin kamu harcaması bilinçlerinin tespit edilmesi ve sonrasında bu bilincin artırılması amaçlanmıştır. Bu amacı gerçekleştirmek için öncelikle öğrencilerin kamu harcaması bilinçlerini de tespit edecek bir anket formu geliştirilmiştir. Söz konusu bu anket üç bölümden oluşmaktadır. Anketin birinci bölümde öğrencilerin demografik özelliklerine, ikinci bölümde vergi bilincine, üçüncü bölümde ise kamu harcamaları bilincine ilişkin sorulara yer verilmektedir.

Anket formu oluşturulduktan sonra Trabzon il Milli Eğitim Müdürlüğü ve Trabzon Valiliğinden gerekli izinler alınmıştır. Daha sonra Trabzon Faruk Başaran Bilim ve Sanat Merkezinde Trabzon'un köyler hariç her yerinden gelen ortaokul ve lise öğrencilerinden gönüllü olan 350 öğrenci ile 10-20 aralığında değişen gruplar ile deney 25-30 dk. aralığında yapılmıştır. Öğrencilerin kamu harcaması bilinçlerinin ölçümünü ve gelişmesini amaçlayan bu çalışma için yapılan deney üç gün süreyle gerçekleştirilmiştir. Bu süre içerisinde kurumda bir bilim şenliği düzenlenmiştir. Buna göre deneye gönüllü olarak katılan öğrenciler, bu bilim şenliğine katılan öğrencilerden oluşmaktadır.

Öğrencilerin eğitiminde ve gelişiminde gerek aile-sosyal çevrenin gerekse de okulda aldıkları eğitimin önemli olduğu söylenebilir. Bu bağlamda deneyin Faruk Başaran Bilim ve Sanat Merkezinde yapılmış olması bu iki faktörden etkilenen tüm öğrenci gruplarına ulaşmaya imkân sağlamaktadır. Böylelikle bu deney, birçok okuldan katılımın sağlanması ve öğrencilerin; köy hariç 
diğer yerleşim yerlerinden, eğitim aldıkları okullarından ve aile-sosyal çevresinden kaynaklanabilecek farklılıklarının ortadan kaldırılmasına da imkân sağlamaktadır. Böylelikle 25-30 dakika aralığında değişen bu deney ile genelleşebilir sonuçlar elde edilmesine imkân sağlanmaktadır.

Daha önce yapılan anket ve mülakat çalışmalarının milli eğitime bağlı okullarda yapıılığı bilinmektedir. Bu bağlamda bu çalışmada kullanılan kurum ve örneklem grubuna yer verilen bir çalışmaya henüz rastlanmamıştır. Buna göre deneyin uygulandığı yer, örneklem grubu ve amacı bu çalışmanın özgün değerleridir.

Modern bir şehri yansıtan halıya deney sürecinde yerleştirilecek semboller ve deneyin tasarlanmasında Miniatur Wunderland'dan ilham alınmıştır (https://www.miniatur-wunderland.de/). Söz konusu bu minyatürde ülkelerde öne çıkan yerlere küçük sembollerle yer verilmekte ve ziyaretçilere sunulmaktadır. Böylelikle küçük bir alanda birçok parçanın bir bütün halinde görülmesi sağlanmaktadır.

1980 sonrasında çeşitli nedenlerden ötürü şehirleşmenin artması ile nüfusun çoğunluğunun şehirlerde yaşadığı söylenebilir. Bu bağlamda bu deneyde; modern bir şehrin tasvirini yansıtan bir halı kullanılmıştır. Deney sürecinde kullanılmak üzere fonksiyonel sınıflandırmaya göre her bir kamu harcama kalemini temsil edebilecek semboller toplanan vergiler karşıllı̆ında kullanılmak üzere halıya yakın bir köşede hazır halde tutulmaktadır.

Deneye geçmeden önce gönüllü öğrencilerden kendi sınıflarına göre (örneğin 6. sınıf) 10-20 öğrencinin olduğu gruplar deneyin yapıldığı alanın dışında gönüllü üniversite öğrencileri tarafından oluşturulmakta ve böylelikle deney gruplarının grup içi uyumluluğu sağlanmaktadır. Bu öğrenciler daha sonra gruplar halinde deney alanına alınmakta ve deneye başlamadan önce anketleri doldurmaları istenmektedir. Söz konusu deney grupları ortaokul ve lise öğrencilerinden oluşmaktadır. Grupların bu şekilde ayrılmalarının nedeni; deneyin ortaokul öğrencilerine daha basitleştirilmiş anlatımla uygulanmasıdır. Bu basitleştirilmiş anlatım için Gelir İdaresi Başkanlığı vergi bilinci geliştirme ortaokul ve lise içeriklerinden yararlanılmıştır (GiB, http://f.eba.gov.tr/gib/).

Anketin tamamlanmasını takiben öğrencilerin halı etrafında toplanmaları istenmektedir. Sonrasında öğrencilere büyüdüklerinde ne olmak istedikleri sorusu yöneltilmekte ve verdikleri cevaplar doğrultusunda, büyüdüklerini varsayarak, onlara para sembolleri ile yapmak istedikleri meslekle orantılı olarak maaş verilmektedir.

Öğrencilere bu güne kadar devletin, onlardan hiçbir karşılık beklemeden bazı hizmetleri yerine getirdiği ama bugün artık onların da ödeme gücüne sahip birer birey oldukları ve bu güce sahip her birey gibi devletin sunduğu bu bazı hizmetlerin finansmanına katılmaları gerektiği bilgisi verilmektedir. Devlet-vergi ve kamu harcamaları arasındaki ilişkiye genel olarak değinildikten sonra şehirde toplumun ihtiyaç duyacağı harcamaların neler olabileceğine ilişkin sorular öğrencilere yöneltilmektedir. Örneğin doktor-hasta arasındaki bir ilişkide sorun yaşanması halinde tarafların nereye başvurmaları gerektiği sorusu öğrencilere yöneltilmiştir. Devamında sorunun çözümü için bir emniyete ve adliyeye ihtiyaç olduğuna grup olarak karar verilmiştir. Böylelikle öğrencilere toplumsal bir ihtiyaç halinde hangi harcamaların meydana geldiği ve bu harcamaların fonksiyonel sınıflandırmaya göre hangi harcama kalemi içerisinde yer aldığı bilgisi verilmektedir. Söz konusu kararın ardından bir adliye inşa edilebilmesi için öğrencilere verilen maaşlardan bir kısmını vergi olarak devlete ödemeleri istenmektedir. Vergiler toplandıktan sonra sembolik bir adliye binası, halıda daha önceden belirlenmiş olan yere yerleştirilmiştir. Böylelikle 
kamu harcamalarının fonksiyonel sınıflandırmaya göre harcama kalemlerinin her biri için bir ihtiyaç oluşturulmakta ve karşılığında vergi ödemeleri istenmektedir. Bu bağlamda öğrencilerin kamu harcamalarının neler olduğu, vergilerin neden gerekli ve önemli olduğu öğrencilerin de sürece aktif bir şekilde dâhil edilmesiyle öğrenmeleri ve mali bağlantı kurmaları sağlanmaktadır. Bu deney süreci tamamlandığında öğrencilerin anketi tekrar doldurmaları sağlanmış ve deney sonlandırılmıştır. Anketlerin ilk doldurulmaları ve son doldurulmaları gönüllü iki üniversite öğrencisi tarafından takip edilmiştir.

\subsection{Araştırmanın Bulguları ve Sonuçları}

Bu başlık altında öğrencilerin anket formundaki kamu harcamaları bilinçlerinin tespitine yönelik oluşturulan soruya ve öğrencilerin cevapları doğrultusunda değerlendirmelere yer verilmektedir. Buna göre öğrencilerin kamu harcaması bilinçlerini ölçmek ve geliştirmek amacıyla anket formunda "Sizce kamu harcaması nedir?" açık uçlu sorusuna verilen cevaplara aşağıda yer verilmektedir. Buna göre ön test- son test bulguları aşağıdaki gibidir.

Ortaokul ön test bulgularında öğrencilerin verdikleri cevaplar göz önünde bulundurularak ve genel olarak kamu harcamalarını;

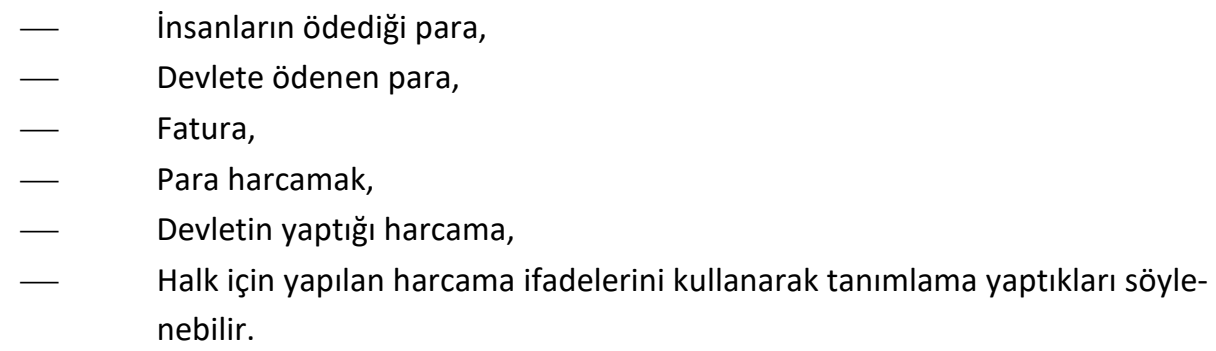

Aynı şekilde lise ön test bulgularında öğrencilerin genel olarak kamu harcamalarını;

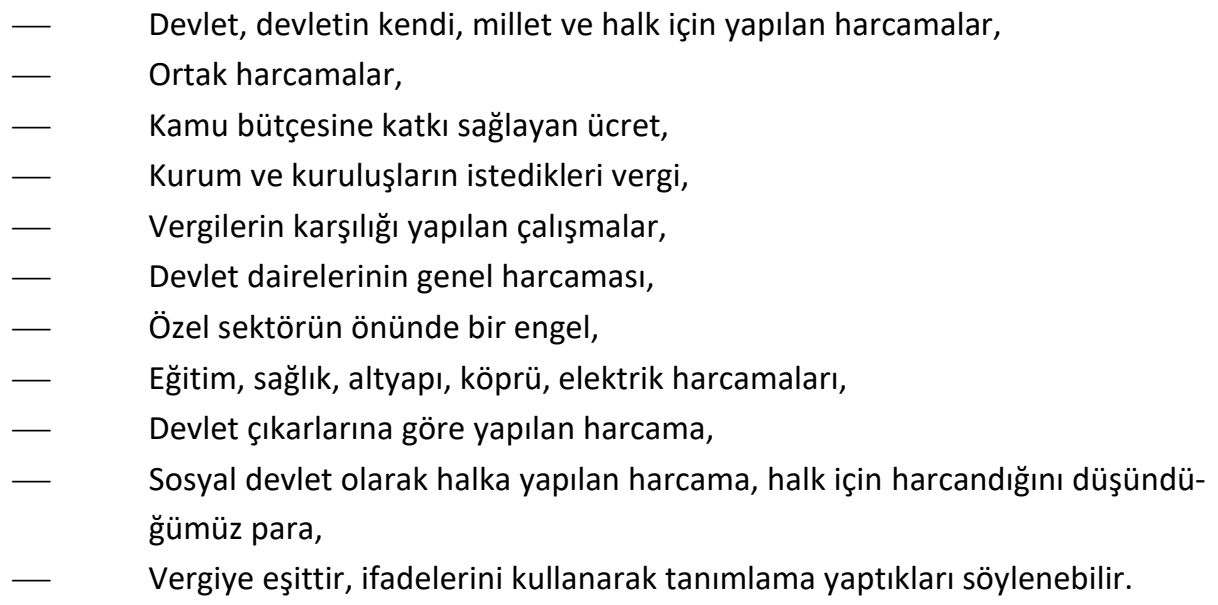

Ortaokul öğrencileri ön test bulgularına göre, öğrencilerin kamu harcaması bilincinin olmadığı söylenebilir. Devletin yaptığı harcamalar ve halk için yapılan harcamalar ifadelerinin kullanılması nedeninin; katılımcı grubun içerisindeki üstün yetenekli öğrencilerin de olması söylenebilir. Lise öğrencileri ön test bulgularına göre, öğrencilerin kamu harcaması bilinçlerinin; kamu harcamalarının halk için yapıldığını, bazı harcama kalemlerini bilmeleri ve finansmanına dair kısmi bilgiye sahip olmaları dolayısıyla oluşmuş olduğu söylenebilir. Ancak kamu harcamalarını 
vergi gibi ve ücret olarak tanımlamaları, eğitim, sağlık ve altyapı harcamaları dışındaki harcamalara yönelik bilgiye sahip olmamaları dolayısıyla gelişmemiş olduğu söylenebilir. Lise öğrencilerinin kamu harcama bilinçlerinin oluşmuş olmasının nedeni olarak yaşlarının ve eğitim seviyesinin yüksek olması, katılımcı grubun içerisinde üstün yetenekli öğrencilerin de olması söylenebilir.

Ortaokul son test bulgularına göre genel olarak kamu harcamalarını;

- Insanların ihtiyaçlarını karşılamak için yapılan harcamalar,

- Tek başımıza yapamayacağımız devletin bizim için yaptığı harcamalar,

- Şehirler için yapılan harcamalar,

- Devletin bize faydalı olan şeyleri yapmak için yaptığı harcamalar,

- Devletin bize verdiği bedel,

- Gereksiz harcamalar,

- Devlet kurumlarının ihtiyaçlarımız için yaptığı harcamalar, ifadelerini kullanarak tanımladığı söylenebilir.

Bu bağlamda deney sonunda ortaokul grubu öğrencilerinin her birinin, kamu harcaması ile ilgili doğru bir tanım beyan ettiği söylenebilir.

Lise öğrencileri son test bulgularına göre genel olarak kamu harcamalarını;

- Devletin bizler için yaptığı harcamalar,

- Özel sektöre engel,

- Boş harcama,

- Halk, toplum yararına yapılan harcama,

- Devletin; kamu düzeni, çevre, sağıı, eğitim, sosyal yardım, kültür, altyapı, iskân ve toplum refahı için yaptığı harcamalar,

- Daha kaliteli ve huzur içinde yaşamak için yapılan harcamalar,

- Gerektiğinde borçlanılarak yapılan harcamalar,

- Ülkenin gelişimi için yapılan harcamalar,

- Devletin yaptığı kişinin yapamayacağı harcamalar,

— Vergilerle yapılan harcamalar, ifadelerini kullanarak tanımladıkları görülmüştür.

Deney sonunda lise grubu öğrencilerinin her birinin, kamu harcaması ile ilgili doğru bir tanım beyan ettiği söylenebilir. Kamu harcaması tanımını özel sektöre engel ve boş harcama olarak yapan öğrencilerin kendilerini bu yönde şartlandırdıkları ve öğrenmeye kapalı oldukları, tüm çabalara rağmen deney sürecinde bu öğrencilerin kamu harcamaları bilincinin oluşturulamadığı gözlemlenmiştir. Ayrıca, gerektiğinde borçlanılarak yapılan harcama ifadesini üstün yetenekli lise öğrencilerinin beyan ettiği görülmektedir. Yukarıdaki ön test ve son test bulguları birlikte değerlendirildiğinde; genel olarak öğrencilerin kamu harcaması bilinçlerinin olmadığı, deney sürecini takiben öğrencilerin tümünün kamu harcaması bilinçlerinin geliştirilebildiği söylenebilir. Bu bağlamda vergi bilincini artırmak için ortaokul ve lise öğrencilerine yönelik yapılan çalışmalar kamu harcaması bilincini artırmak için genişletilerek mali bilincin artırılması sağlanabilir. Bu durumda vergi ile mevcut alışkanlıklarını değiştirmek çok güç olan yetişkin mükelleflere, eğitim 
hayatlarında vergi bilinci yanında kamu harcaması bilincinin de öğretilmesi ile mali bağlantı kurmalarına yardımcı olunabilir ve böylelikle uzun vadede mali bilince sahip bir başka ifade ile mali bağlantıyı tam kurabilen mükelleflerin kazanılabileceği söylenebilir.

Deney süresince toplumun eğitim, sağlık ve savunma harcamalarına yönelik olan ihtiyaçlarının, öğrenciler tarafından kolayca ihtiyaç yaratılabildiği, tahmin edilebildiği, bilindiği ve bu harcamalara yönelik bilgileri çabuk kavrayabildikleri ve böylelikle mali bağlantıyı daha kolay kurdukları gözlemlenmiştir. Öte yandan genel kamu hizmetleri, ekonomik işler ve hizmetler için ihtiyaç oluşturmakta ve bu harcamaları somutlaştırmakta güçlük çektikleri de gözlemlenmiştir. Deney sürecinde öğrencilerin; deney sürecini, devlet-idare-vergi- harcama sürecini kısa sürede benimsedikleri ve deneye kolayca adapte oldukları gözlemlenmiştir.

\section{Kamu Harcaması Bilinci Tespitine Yönelik 5'li Likert Ölçeği Kullanılan Soru Geliştirilmesi}

Açık uçlu olmayan anket soruları, örnekleme yöneltilen açık uçlu sorulara verilen cevaplar doğrultusunda hazırlanmaktadır. Bu bağlamda bu başlık altında ortaokul ve lise öğrencilerine açık uçlu olarak yöneltilen Sizce Kamu Harcaması Nedir? sorusuna verdikleri cevaplar doğrultusunda, kamu harcaması bilincini tespit etme amacına yönelik 5'li Likert ölçekli soru geliştirilmektedir. Bu soru gelecek çalışmalarda öğrencilerin kamu harcaması bilincinin tespit edilmesinde kullanılması için geliştirilmiştir. Böylelikle Likert ölçekli bu sorunun, açık uçlu soruya kıyasla değerlendirmesinin daha kısa ve kolay olmasının gelecek çalışmalar için yararlı olacağı ve ilgili literatüre katkı sağlayacağı düşünülmektedir. Geliştirilen bu soruya Tablo 4'te yer verilmektedir.

Tablo 4: Kamu Harcaması Bilincinin Tespitine Yönelik 5’li Likert Ölçeğinin Kullanılması

\begin{tabular}{|c|c|c|c|c|c|}
\hline Kamu Harcaması Nedir? & $\begin{array}{c}\text { Kesinlikle } \\
\text { Katılmıyorum }\end{array}$ & Katılmıyorum & $\begin{array}{c}\text { Kısmen } \\
\text { Katılıyorum }\end{array}$ & Katılıyorum & $\begin{array}{l}\text { Kesinlikle } \\
\text { Katılıyorum }\end{array}$ \\
\hline $\begin{array}{l}\text { Devletin; kamu düzeni, çevre, sağ- } \\
\text { lık, savunma, eğitim, sosyal yar- } \\
\text { dım, kültür, altyapı, iskân ve top- } \\
\text { lum refahı için yaptığı harcamalar }\end{array}$ & ( ) & ( ) & ( ) & ( ) & ( ) \\
\hline $\begin{array}{c}\text { Özel sektöre engel olan ve boş } \\
\text { olan harcamalar }\end{array}$ & $(1)$ & ( ) & $(1)$ & ( ) & ( ) \\
\hline $\begin{array}{l}\text { Devletin yaptığı ve karşılığında } \\
\text { vergi aldığı harcamalar }\end{array}$ & ( ) & ( ) & $(1)$ & ( ) & ( ) \\
\hline $\begin{array}{c}\text { Kamu bütçesine katkı sağlayan } \\
\text { ücret }\end{array}$ & ( ) & ( ) & ( ) & ( ) & ( ) \\
\hline $\begin{array}{l}\text { Devlet tarafından yapılan, önemli } \\
\text { ve gerekli olan harcamalar }\end{array}$ & ( ) & ( ) & ( ) & ( ) & ( ) \\
\hline $\begin{array}{c}\text { Devlet kurumlarının ihtiyaçlarımız } \\
\text { için yaptığı harcamalar }\end{array}$ & ( ) & ( ) & ( ) & ( ) & ( ) \\
\hline Fatura & ( ) & ( ) & ( ) & ( ) & ( ) \\
\hline
\end{tabular}




\section{Sonuç}

Vergi uyumunun artırılması için mali bağlantının kurulmasına, mali bağlantının kurulması için mali bilince, mali bilincin oluşması için de vergi ve kamu harcaması bilinçlerinin oluşmasına intiyaç duyulduğu söylenebilir. Bu çalışma gelecekteki vergi mükelleflerinin vergi uyumunun artırıması için kamu harcaması bilincinin tespiti ve geliştirilmesi amacına yönelik olarak hazırlanmıştır. Bu bağlamda Trabzon ilinde bir deney çalışması yürütülmüştür. Deney öncesi ve sonrası uygulanan anket ile öğrencilerin öncelikle kamu harcaması bilinçlerinin tespiti yapılmış, sonrasında ise bilinçlerinin geliştirilmesi için önerilerde bulunulmuş ve öğrencilerin kamu harcaması bilinçlerini tespit eden açık uçlu soruya verilen cevaplar doğrultusunda $5^{\prime}$ li Likert ölçeğinin kullanıldığı bir soru geliştirilmiştir.

Deney öncesi ve sonrasında kamu harcaması bilincinin tespitine yönelik olarak öğrencilere "Sizce Kamu Harcaması Nedir" sorusu yöneltilmiştir. Buna göre genel olarak öğrencilerin deney öncesinde kamu harcaması bilinçlerinin olmadığı, deney sonrasında deneye katılan her öğrencinin kamu harcaması bilincine sahip olduğu ve mali bağlantı kurabildiği tespit edilmiştir. Böylelikle çalışmada kullanılan yöntemin gelecekteki vergi mükelleflerinin gönüllü vergi uyumunu artırmada başarılı olabileceği görülmüştür. Gelecek çalışmalarda öğrencilerin kamu harcaması bilincini tespit etmek için geliştirilen 5 'li Likert sorusu kullanılabilir. Böylelikle öğrencilerin anket doldurma süreleri ve anket sorusunun değerlendirilmesi süresi kolaylaştırılıp azaltılabilir.

Bu çalışmada deneye katılan öğrenciler Trabzon'un köy hariç ortaokul ve lise öğrencileridir. Bu bağlamda gelecek çalışmalarda köy okullarında okuyan öğrencilerin de deneye katılımı sağlanarak örneklem grubu genişletilebilir. Böylelikle tüm öğrencilere ulaşılmış olup daha detaylı gözlemlerin yapılabileceği bir ortam meydana getirilebilir. Çalışmanın yönteminin Türkiye'de farklı illerde uygulanması suretiyle, Türkiye'deki öğrenciler için bir kamu harcaması bilinci tablosu ortaya konulabilir. Deney esnasında kullanılan halının ebatı büyütülerek gruplarda daha fazla öğrenciyle çalışma imkânı sağlanabilir. Ayrıca deney için kullanılan halının öğrencilerin yaşadığı şehrin bir görüntüsü niteliğinde olması ve üzerinde kamu harcaması yapılan yerlerin Türkçe isimlerle yazılı halinin basılmış olmasının kullanılan bu yöntemin kalitesini artıracağı söylenebilir ve böylelikle deneyin öğrencilerde daha kalıcı izler bırakması sağlanabilir.

Jamaika'da 2011 yılında "School Taxpayer's Education Programme" ile 10, 11 ve 12. sınıf öğrencilerine vergiler, kamu harcamaları, mükelleflerin vergilerini nasıl ödeyecekleri, gelir idareleri ve mükellef haklarını içeren eğitimler verilmiştir (OECD, 2015: 91). Gelecek çalışmalarda vergi ve kamu harcaması bilincine ilişkin deney senaryolarına öğrencilerin mükellef olduklarında vergilerini nası ödeyebilecekleri, öğrencilerin ilgisini çekecek şekilde gelir idaresi hakkındaki temel bilgiler, kamu harcamaları bilinçlerini artırabilecek bilgiler ve mükellef hakları ile ilgili bilgiler eklenerek uyumlu mükellefler olarak yetiştirilmeleri sağlanabilir. Böylesi deneyler vergi haftasında da gerçekleştirilebilir. Böylece öğrencilerin eğitim süreçlerinde onları uyumlu mükellef yapabilecek önlemlerin artırılmış olması ile mali bilincin ve gönüllü vergi uyumunun artırılabileceği söylenebilir. 


\section{Eskişehir Osmangazi Üniversitesi IïB Dergisi}

\section{Kaynaklar}

Çelik, Kadir; Eroğlu Onur (2014), "ilköğretim Çağında Vergi Algısının İncelenmesi: Zonguldak îli Örneği”, Çankırı Karatekin Üniversitesi Iktisadi ve Idari Bilimler Fakültesi Dergisi, Vol. 4, No. 2: 301-326.

Demir, İhsan Cemil (2009), “Kamu Harcamalarının Toplumsal Algısı: Ampirik Bir Araştırma”, Maliye Dergisi, No. 157: 2010-226.

Demir, İhsan Cemil; Ciğerci İsmail (2016), "Vergi Bilincinin Oluşumunda Eğitimin Rolü: İlköğretim Öğrencileriyle Amprik Bir Çalışma”, Yönetim ve Ekonomi, Vol. 23, No. 1: 127-143.

GiB [Gelir İdaresi Başkanlı̆̆ı], http ://f.eba.gov.tr/gib/, (Erişim: 18.09.2018).

GiB [Gelir İdaresi Başkanlı̆̆ı], http://www.gib. gov.tr/node/103186, (Erişim: 18.09.2018).

Goldscheid, Rudolf (1958), "A Sociological Approach to Problems of Public Finance", Classics in the Theory of Public Finance, (Ed. Richard Musgrave; Alan Peacock), St Martin Press: London: 202-213.

Göksu, T. (2007), "Sosyal Psikoloji", http://www.turgutgoksu.com/FileUpload/ks7441/ File/spalgymart12.pdf, (Erişim: 02.07.2019).

Karaca, Rukiye (2015), “Vergi Bilinci ve Vergi Algısı: Kütahya İlinde İlköğretim Öğrencileri Üzerine Bir Araştırma”, Dumlupınar Üniversitesi Sosyal Bilimler Enstitüsü, (Yayımlanmamış Yüksek Lisans Tezi), Kütahya.

Karaot, Ali (2010), “ilköğretim Çağındaki Öğrencilerin Vergi Bilinç Düzeyi: İzmir İli Aliağa İlçesi Örneği”, Çanakkale Onsekiz Mart Üniversitesi Sosyal Bilimler Enstitüsü, (Yayımlanmamış Yüksek Lisans Tezi), Çanakkale.

Miniatur Wunderland, https://www.miniatur-wunderland.de/, (Erişim: 07.07.2016).

OECD [The Organisation for Economic Co-operation and Development] (2015), Building Tax Culture, Compliance and Citizenship A Global Source Book on Taxpayer Education, https://www.oecd.org/publications/building-tax-culturecompliance-and-citizenship-9789264205154-en.htm, (Erişim: 27.03.2018).

Pehlivan, Osman (2015), Devlet Bütçesi, Genişletilmiş 2. Baskı, Trabzon: Celepler Matbaacılık.

Sağbaş, İsa; Başoğlu Âdem (2005), "Illköğretim Çağındaki Öğrencilerin Vergileri Algılaması: Afyonkarahisar İli Örneği”, Afyon Kocatepe Üniversitesi IiBF Dergisi, Vol. 7, No. 2: 123-144.

Schmölders, Günter (1976), Genel Vergi Teorisi, Çev., Salih Turhan: İstanbul Üniversitesi Yayınları.

Strateji Geliştirme Başkanlığı, http://www.sgb.adalet.gov.tr/ekler/odenekler/analitik-butce-siniflandirma-rehberi.pdf, (Erişim: 10.11.2017).

Taytak, Mustafa (2010), “ilköğretim II: Kademe Öğrencilerinde Vergi Bilincinin Tespiti: Amprik Bir Araştırma”, Maliye Dergisi, No. 158: 496-512.

Zorlu, Ömür (2012), “ilköğretim Çağındaki Öğrencilerin Vergi Bilinci Düzeyi ve Vergi Bilinci Düzeyi İle İlgili Örnek Uygulama (Ankara ilii Örneği)”, Gazi Üniversitesi Eğitim Bilimleri Enstitüsü, (Yayımlanmamış Yüksek Lisans Tezi), Ankara. 


\section{Extended Summary}

\section{An Experiment for Determining and Developing Public Expenditure Awareness of Secondary and High School Stu- dents}

It is difficult to change their tax-related habits of adult taxpayers. Therefore, it is important to carry out studies for students who maybe taxpayers of the today or future. In order to improve students' financial awareness, public expenditure awareness should be improved. Accordingly, the purpose of this study is to determine and improve students' public expenditure awareness.

It is known that students are given training on taxes, public expenditures, how to pay taxpayers' taxes, income administration and taxpayer rights (OECD, 2015: 91). Which determine the students' tax awareness and develops studies were conducted in Turkey (Sağbaş and Başoğlu, 2005; Karaot, 2010; Taytak, 2010; Zorlu, 2012; Çelik and Eroğlu, 2014; Karaca, 2015; Demir and Ciğerci, 2016;). Public expenditure awareness: It can be defined as the taxpayers' knowledge of public expenditures and at the same time having the knowledge that these expenditures are in line with the needs of the society.

On June 13, 2007, "verGiBilir Protocol" was signed between T.R. Ministry of Finance and Treasury , and T.R. Ministry of National Education. "The main purpose of this protocol is to ensure that children have a positive attitude towards tax or change their current attitude positively". For simplified narration in the experiment scenario, the Revenue Administration's tax awareness development secondary school and high school contents were used.

It is known that the previous surveys and interviews in Turkey were carried out in schools connected to national education. In this study experimenting with 350 students volunteering from secondary school and high school students from all parts of Trabzon, except villages, with groups ranging between 10-20, 25-30 min was made in the range at Trabzon Faruk Başaran Science and Arts Center. The experiment for this study, which aims to measure and develop the awareness of students' public expenditure, was carried out for three days. During this period, a science festival was held at the institution. Accordingly, the students participating in the experiment voluntarily consist of the students participating in this science festival. In this context, a study including the institution and sample group used in this study has not been found yet. Accordingly, the place, sample group and purpose of the experiment are the unique values of this study.

The open-ended question (What is Public Expenditure for You?) was directed to the students in order to determine that their public expenditure awareness before the experiment. Then, an experiment was developed that developed students' public expenditure awareness. In the experiment; A carpet reflecting the depiction of a modern city was used. The symbols that will be placed on the carpet reflecting a modern city are inspired by Miniatur Wunderland, in Germany, in designing the experiment. In this miniature, the places that stand out in the countries are given with small symbols and presented to the visitors. Thus, it is possible to see many parts as a whole in a small area. The symbols that can represent each of the public expenditure items according to the functional classification for use in the experimental process are kept ready in a corner close to the carpet to be used in exchange for the collected taxes.

Groups of volunteer students participating according to their own classes (6th grade e.g.) were formed. These students are then taken to the experimental area in groups and are asked to complete the question about public expenditure before starting the experiment. Following the completion of the question, students are asked to gather around the carpet. Then, the students are asked the question of what they want to be when they grow up, and in line with their answers, they are given a salary in proportion to the profession they want to do with money symbols, assuming they have grown. The students are informed that the state has performed some services without expecting any response from them to this day, but they are individuals who have the power to pay and that they should participate in the financing of some of the services offered by the state like every individual with this power now. After addressing the relationship between state-tax and public expenditure in general, question about what the society will need in the city are asked to the students. In this way, students are given information about which expenditures occur in case of a social needs and in which expenditure item these expenditures are included according to functional classification. After determining the needs, students are asked to pay some of the salaries given to the government as tax. After the taxes are collected, public expenditure symbols are placed on the carpet at the predetermined place. Thus, a need is created for each of the expenditure items according to the functional classification of public expenditures and tax payments are requested in return.

After the experiment, the open-ended question was directed to the students again and their public expenditure awareness was determined. In general, it was determined that students' public expenditure awareness was low before the experiment. Additionally public expenditure awareness of high school students is better than that of secondary 


\section{Eskişehir Osmangazi Üniversitesi ïiBF Dergisi}

school students. Students' public expenditure awareness was high after the experiment and thus improved. Likert scale question What is Public Expenditure? has been developed, which determines the public expenditure awareness of the students for use in future studies with the findings obtained in this study. The question is as follows.

\begin{tabular}{|c|c|c|c|c|c|}
\hline What is Public Expenditure? & $\begin{array}{l}\text { I Strongly Di- } \\
\text { sagree }\end{array}$ & I Disagree & $\begin{array}{l}\text { I Partially Ag- } \\
\text { ree }\end{array}$ & I Agree & $\begin{array}{l}\text { I Strongly } \\
\text { Agree }\end{array}$ \\
\hline $\begin{array}{l}\text { The State; expenditure on public } \\
\text { order, environment, health, de- } \\
\text { fense, education, outreach, cul- } \\
\text { ture, infrastructure, housing and } \\
\text { community welfare }\end{array}$ & ( ) & ( ) & ( ) & ( ) & ( ) \\
\hline $\begin{array}{l}\text { Expenditures that prevent private } \\
\text { sector and are unnecessary. }\end{array}$ & ( ) & ( ) & $(1)$ & ( ) & ( ) \\
\hline $\begin{array}{l}\text { Expenditures made by the state } \\
\text { and received taxes in return }\end{array}$ & ( ) & ( ) & ( ) & ( ) & ( ) \\
\hline $\begin{array}{l}\text { The fee that contributes to the } \\
\text { public budget }\end{array}$ & ( ) & ( ) & ( ) & ( ) & ( ) \\
\hline $\begin{array}{l}\text { Significant and necessary expen- } \\
\text { ditures by the state. }\end{array}$ & ( ) & ( ) & ( ) & ( ) & ( ) \\
\hline $\begin{array}{l}\text { Expenditure by government agen- } \\
\text { cies for our needs. }\end{array}$ & ( ) & ( ) & ( ) & ( ) & ( ) \\
\hline Invoice & ( ) & ( ) & ( ) & ( ) & ( ) \\
\hline
\end{tabular}

